\title{
Effects of Machining Conditions on Surface Roughness in Planing and Sanding of Solid Wood
}

\section{Utjecaj uvjeta obrade na hrapavost površine pri blanjanju i brušenju masivnog drva}

\author{
Original scientific paper • Izvorni znanstveni rad \\ Received-prispjelo: 19. 2. 2014. \\ Accepted-prihvaćeno: 6. 11. 2015. \\ UDK: $630 * 823.121 ; 630 * 823.22$ \\ doi:10.5552/drind.2015.1406
}

\begin{abstract}
It is important to evaluate the effect of machining and wood machining properties on surface quality to determine and upgrade the data on wood machining properties and to define convenient usage areas for some native wood species of Turkey. European black pine (Pinus nigra Arnold) and cedar of Lebanon (Cedrus libani A. Rich) are two softwood species and sessile oak (Quercus petraea Lieble) and black poplar (Populus nigra L.) are two hardwood species commonly used and grown in Turkey. These trees species were selected as experimental material for the study. Roughness measurements are significant in the determination of wood surface quality for use as a final product. This study evaluated roughness measurements after planing and sanding operations, and found that the highest value for average roughness (Ra) was observed as $6.780 \mu \mathrm{m}$. in sessile oak, followed by black poplar at $6.338 \mu \mathrm{m}$, cedar of Lebanon at $4.836 \mu \mathrm{m}$, and black pine at $4.740 \mu \mathrm{m}$. The average roughness values for wood in directions perpendicular to the grain and along the grain from highest to lowest were sessile oak, black poplar, black pine, and cedar of Lebanon.
\end{abstract}

Key words: Wood, surface roughness, planing, sanding

SAŽETAK • Istraživanje utjecaja mehaničke obrade i svojstava drva na kvalitetu obrađene površine važno je kako bi se dopunili podaci o svojstvima drva pri mehaničkoj obradi i definirala prikladna područja upotrebe nekih domaćih vrsta drva u Turskoj. Europski crni bor (Pinus nigra Arnold) i libanonski cedar (Cedrus libani A. Rich) dvije su meke vrste drva, a hrast kitnjak (Quercus petraea Lieble) i crna topola (Populus nigra L.) dvije su tvrde vrste drva koje se često upotrebljavaju i uzgajaju u Turskoj. Te su četiri vrste drva odabrane za istraživanje hrapavosti pri mehaničkoj obradi. Mjerenje hrapavosti važno je za određivanje kvalitete površine drva gotovog proizvoda. U ovom se istraživanju ocjenjuje izmjerena hrapavost drva nakon njegova blanjanja $i$ brušenja. Utvrđeno je da je najveća izmjerena vrijednost prosječne hrapavosti (Ra) iznosila 6,780 um na uzorcima drva hrasta kitnjaka te 6,338 um na uzorcima drva crne topole, dok je na uzorcima drva libanonskog cedra izmjerena

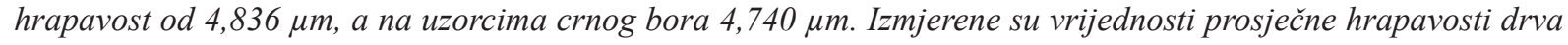
u smjeru okomito na vlakanca i uzduž vlakanaca, od najviše do najniže, na uzorcima hrasta kitnjaka, crne topole, crnog bora i libanonskog cedra.

Ključne riječi: drvo, hrapavost površine, blanjanje, brušenje

\footnotetext{
${ }^{1}$ Author is PhD at Department of Wood Works Industrial Engineering, Faculty of Simav Technology, Dumlupinar University, Simav/Kutahya, Turkey. ${ }^{2}$ Author is professor at Department of Interior Architecture, Faculty of Fine Arts and Design, Dogus University, Acibadem, Kadikoy/ Istanbul, Turkey.

${ }^{1}$ Autor je doktor znanosti u Odjelu za industrijsku obradu drva, Tehnološki fakultet, Sveučilište Dumlupinar, Simav/Kutahya, Turska. ${ }^{2}$ Autor je profesor Odjela za unutarnje uređenje, Fakultet likovne umjetnosti i dizajna, Sveučilište Dogus, Acibadem, Kadikoy/Istanbul, Turska.
} 


\section{INTRODUCTION}

\section{UVOD}

In wood finishing, roughness reflects faults on a wood surface as a result of the operations carried out in production. These faults are repeated with a low probability and periodically. Control and monitoring of surface roughness is required to maintain product quality at the same level throughout the production, as this property affects wood adhesion and changes can increase loss. After solid wood undergoes machining by sawing, planing, sanding, etc., it becomes a final product. Wood finishing is an important factor in determining the economic value of the final product. Accordingly, surface roughness is a definitive property for measuring the success of the wood finish.

Surface roughness can be evaluated quantitatively and qualitatively. Each approach has advantages and disadvantages, such as a slower speed, sensitivity, and the accuracy of results (Malkocoglu, 1999). There are various methods of surface roughness measuring in the area of woodworking. Lumber surface roughness can be measured with an airflow method (Porter, 1971). An imaged light and needle-scan can also measure surface roughness (Peters, 1970). It is thought that surface roughness in industrial applications can be easily done with a light-sectioning shadow scanner method (Sandak, 2005). However, the stylus trace method has emerged as the most suitable and applicable method in the measurement of surface roughness (Peters, 1971; Faust, 1987).

Stumbo (1960) mentioned that a decrease in surface roughness will occur with an increase in the cutter speed and number of teeth in cutting saws. An increase in surface roughness will occur with an increase in feeding speed. When planing and milling softwood species compared to hardwood species, roughness is greater when cutting perpendicular to the grain than when cutting along the grain. In general, worn cutters increase surface roughness. With regards to average roughness values, approximately the same values are obtained in directions perpendicular to the grain and along the grain (Steward, 1970).

Roughness of various tree species has been investigated. Gurleyen (1998) studied surface roughness in the planing of beech (Fagus orientalis L.), scotch pine (Pinus sylvestris L.), sessile oak (Quercus petreae L.), and black locust (Robinia pseudoacacia L.). Demirci (1998) studied oriental beech (Fagus orientalis L.), scotch pine (Pinus sylvestris L.), oak (Quercus petreae L.), and black locust (Robinia pseudoacacia L.) in the machining of massive wooden material with circular saws. Ors et al. (1999) studied the planing and sanding operations of planed and sanded massive wooden material using oriental beech and Scotch pine. Kantay et al. (2001) studied the surface roughness of sliced veneer boards from tree species of walnut (Juglans regia L.) and oriental beech (Fagus orientalis L.) in Turkey. Ünsal et al. (2002) studied the surface roughness of massive parquets from oak and oriental beech in Turkey using a stylus trace method. Ilter et al.
(2002) studied surface roughness in planing and sanding of Uludag fir (Abies bornmülleriana Mattf.). Efe et al. (2003) carried out surface roughness measurements in planing experiments conducted under various conditions on black locust (Robinia pseudoacacia L.) and walnut (Juglans regia). Kilic et al. (2003) studied surface roughness in the sawing of wood from Scotch pine (Pinus sylvestris L.) and chestnut (Castania sativa mill.). Ors et al. (2003) determined surface roughness in the sanding of wood from black locust (Robinia pseudoacacia L.) and oak (Quercus petrea L.) using a stylus trace method. Aslandogan (2005) determined the surface roughness after planing and sanding experiments of European black pine (Pinus nigra Arnold) that were artificially grown. Sogutlu (2005) determined surface roughness in sanding of black locust (Rubinia pseudoacacia L.), European pear (Pirus communis L.), chestnut (Castanea sativa Mill.), oak (Quercus petrea Lieble) and cedar of Lebanon (Cedrus libani A.Rich) grown in Turkey. Sonmez et al. (2005) determined surface roughness in the planing of wood from Black locust (Rubinia pseudoacacia L.), European pear, chestnut, oak and cedar of Lebanon.

Aras et al. (2007) evaluated surface roughness in the turning of walnut (Juglans regia L.), oriental beech (Fagus orientalis L.), largeleaf linden (Tilia grandifolia Ehrh.) and aspen (Populus tremula L.) with a stylus trace method. Malkocoglu (2007) investigated planing properties and surface roughness of oriental beech (Fagus orientalis Lipsky.) grown in the Eastern Black sea region, Anatolian chestnut (Castenea sativa Mill.), black alder (Alnus glutinosa), Scots pine (Pinus sylvestris L.) and oriental spruce (Picea orientalis (L.). It was observed that using veneer with tough surfaces in plywood production reduced adhesion quality (Faust, 1986). Hiziroglu et al. (2013) determined surface roughness in the sanding of pine (Pinus strobus), borneo camphor (Dryobalanops spp.) and meranti (Shorea spp). Zhong et al. (2007) evaluated surface roughness in various commercially produced composite panels including particleboard, medium density fibreboard (MDF), and plywood in addition to ten different solid wood species which are commonly used in furniture production. Skaljic et al. (2009) determined surface roughness values of planed beech-wood (Fagus L.), oak - wood (Quercus L.) and fir-wood (Abies alba Mill.) specimens.

This study investigated and evaluated surface roughness through planing and sanding experiments for several hardwood and softwood species commonly used in Turkey.

\section{MATERIAL AND METHODS} 2. MATERIJAL I METODE

\subsection{Wood material}

\subsection{Uzorci drva}

Various species of softwoods and hardwoods were used for the experiments. European black pine (Pinus nigra Arnold) and cedar of Lebanon (Cedrus libani A. Rich), as two softwood species, and Sessile Oak (Quer- 
...... Dündar Sofuoğlu, Kurtoğlu: Effects of Machining Conditions on Surface Roughness...

Table 1 Machining conditions of planing experiments

Tablica 1. Uvjeti obrade tijekom provedbe eksperimenta pri blanjanju

\begin{tabular}{|l|c|c|c|c|}
\hline & $\begin{array}{c}\text { Number of knives } \\
\text { Broj noževa }\end{array}$ & $\begin{array}{c}\text { Feed rate } \\
\text { Posmična brzina } \\
\mathrm{m} / \text { min }\end{array}$ & $\begin{array}{c}\text { Number of knife marks per cm } \\
\text { Broj prolazaka noža po 1 cm }\end{array}$ & $\begin{array}{c}\text { Cutting angles, }^{\circ} \\
\text { Kut rezanja, }^{\circ}\end{array}$ \\
\hline Run 1 / Prolazak1. & 4 & 8.6 & 4.72 & 25 \\
\hline Run 2 / Prolazak 2. & 4 & 18 & 2.36 & 25 \\
\hline Run 3 / Prolazak3. & 2 & 8.6 & 4.72 & 15 \\
\hline Run 4 / Prolazak 4. & 2 & 8.6 & 4.72 & 20 \\
\hline
\end{tabular}

cus petraea Lieble) and black poplar (Populus nigra L.), as two hardwood species commonly used and grown in Turkey, were selected as experimental material for the study. The samples were all randomly selected from naturally grown wood in Istanbul and Kutahya in Turkey. The wood was conditioned at a temperature of $20 \pm$ $2{ }^{\circ} \mathrm{C}$ and $65 \pm 5 \%$ to a moisture content of about $12 \%$. 30 specimens $(25 \times 102 \times 910 \mathrm{~mm})$ were used for each planing and sanding test according to ASTM standard D 1666 (2004) (ASTM International, 2004).

\subsection{Performance of planing and sanding experiments}

2.2. Provedba eksperimenta pri blanjanju i brušenju

Planing experiments were carried out using a TORK brand K500-X250 model thickness planer at the facility of the Istanbul University, Forestry Faculty of Furniture and Wood Machining. Thirty test samples with the dimensions $25 \times 102 \times 910 \mathrm{~mm}$ and a wood moisture content of $12 \%$ were made from each tree species. As stated in the above said standard (ASTM D-1666), the cutting depth was $1.6 \mathrm{~mm}$ for all the cuts. The properties of the cutting tools used in the planing tests are presented in Table 1.

A wide-belt caliber sander, Melkuc Kombi 650 model, for calibrating and sanding of wood based panels was used for the sanding experiments. The cutting speed in sanding operation was set to $5.5 \mathrm{~m} / \mathrm{min}$. The samples previously used in the planing experiments with dimensions of $20 \times 102 \times 910 \mathrm{~mm}$ were first sanded with 80 grain sandpaper and then with a 120 grain.

\subsection{Roughness measurement}

2.3. Mjerenje hrapavosti

The measurement of surface roughness was done according to protocols in TS 6956 EN ISO 4287, TS 971, and TS 2495 EN ISO 3274. An instrument for measuring surface roughness, Mitutuyo Surfjet SJ 301, was used for the determination of surface roughness by a contact stylus trace method.

Measurements were made in two different directions, perpendicular and along the grain. Gaussian filter type was used. Sampling length was $2.5 \mathrm{~mm}$ and the evaluation length was $L_{\mathrm{t}}=12.5 \mathrm{~mm}$. Cut-off length was $2.5 \mathrm{~mm}$. Surface roughness values were measured with a sensitivity of $\pm 0.01 \mu \mathrm{m}$. Tool measurement speed was $10 \mathrm{~mm} / \mathrm{min}$, the diameter of the measurement needle was $4 \mu \mathrm{m}$, and the needle tip $90^{\circ}$. Care was taken to have a measurement environment around $18^{\circ} \mathrm{C}-22^{\circ} \mathrm{C}$, away from noise sources, and without vibration. The tool was calibrated before the measurement and the calibration was checked at established intervals.

\subsection{Statistical methods used}

2.4. Statističke metode

Arithmetic mean and standard deviation were used for the evaluation of the specific gravity and the number of annual rings per $\mathrm{cm}$. In the evaluation of roughness results, correlation analysis, analysis of variance (ANOVA), and also a t-test were employed to investigate whether there is a significant difference between the roughness values with respect to the applied measurement directions.

\section{RESULTS AND DISCUSSION 3. REZULTATI I RASPRAVA}

Wood species with various specific gravity were selected: European black pine $\left(0.6526 \mathrm{~g} / \mathrm{cm}^{3}\right)$, cedar of Lebanon $\left(0.5019 \mathrm{~g} / \mathrm{cm}^{3}\right)$, sessile oak $\left(0.7767 \mathrm{~g} / \mathrm{cm}^{3}\right)$, black poplar $\left(0.3412 \mathrm{~g} / \mathrm{cm}^{3}\right)$. The mean for the number of rings per $\mathrm{cm}$ was also calculated for each species: European black pine (3.484), cedar of Lebanon (1.768), sessile oak (4.660), and black poplar (0.780).

A total of 8 roughness measurements were conducted on 4 fixed points established on each machine in directions perpendicular to the grain and along the grain on 30 planed samples. A Ra (average roughness) value was used in the evaluation of results of roughness measurement.

There is a very weak correlation between roughness, a dependent variable, and the number of annual rings per $\mathrm{cm}$ and the specific weight, an independent variable, at 0.097 and -0.038 , respectively. However, a strong positive correlation is observed between the number of annual rings per $\mathrm{cm}$ and the specific weight, an independent variable at 0.804 . The data obtained from the experiments is given in Table 2 .

Figure 1a below shows roughness values along the grain for various machining conditions and tree species. Figure 1b shows the roughness perpendicular to the grain. Figure 1c provides the mean of the roughness values perpendicular to the grain and along the grain in the form of a graph.

Table 3 provides average roughness values, standard errors based on tree species, and lower and upper limits based on a $95 \%$ confidence limit.

With respect to tree species, oak had the highest roughness average with $6.780 \mu \mathrm{m}$, followed by black poplar with $6.338 \mu \mathrm{m}$. With regards to the upper and lower limits of tree species based on a $95 \%$ confidence level, the confidence ranges of pine and cedar of Lebanon intersect. When roughness values are studied based on machining conditions, the highest average 

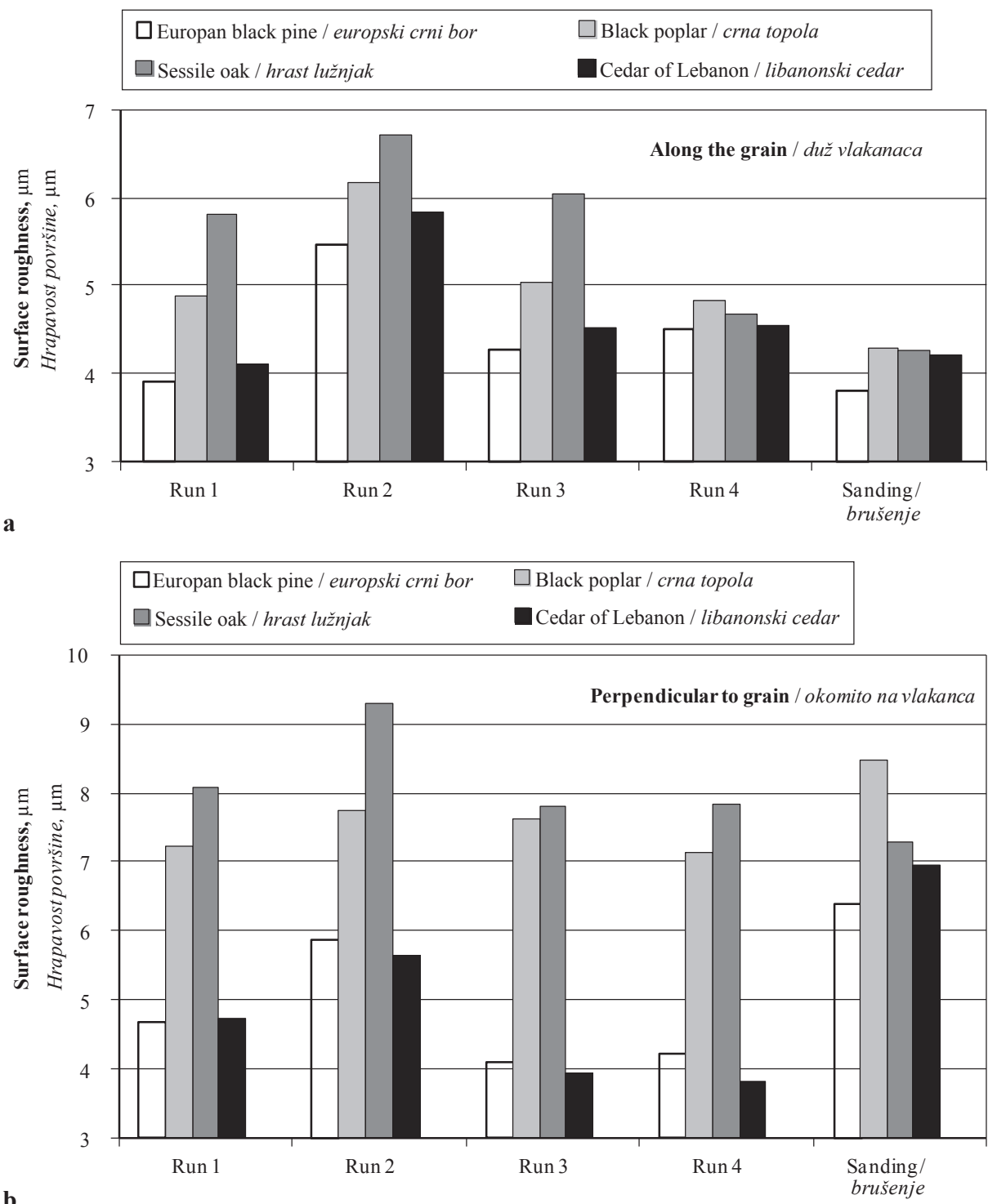

b

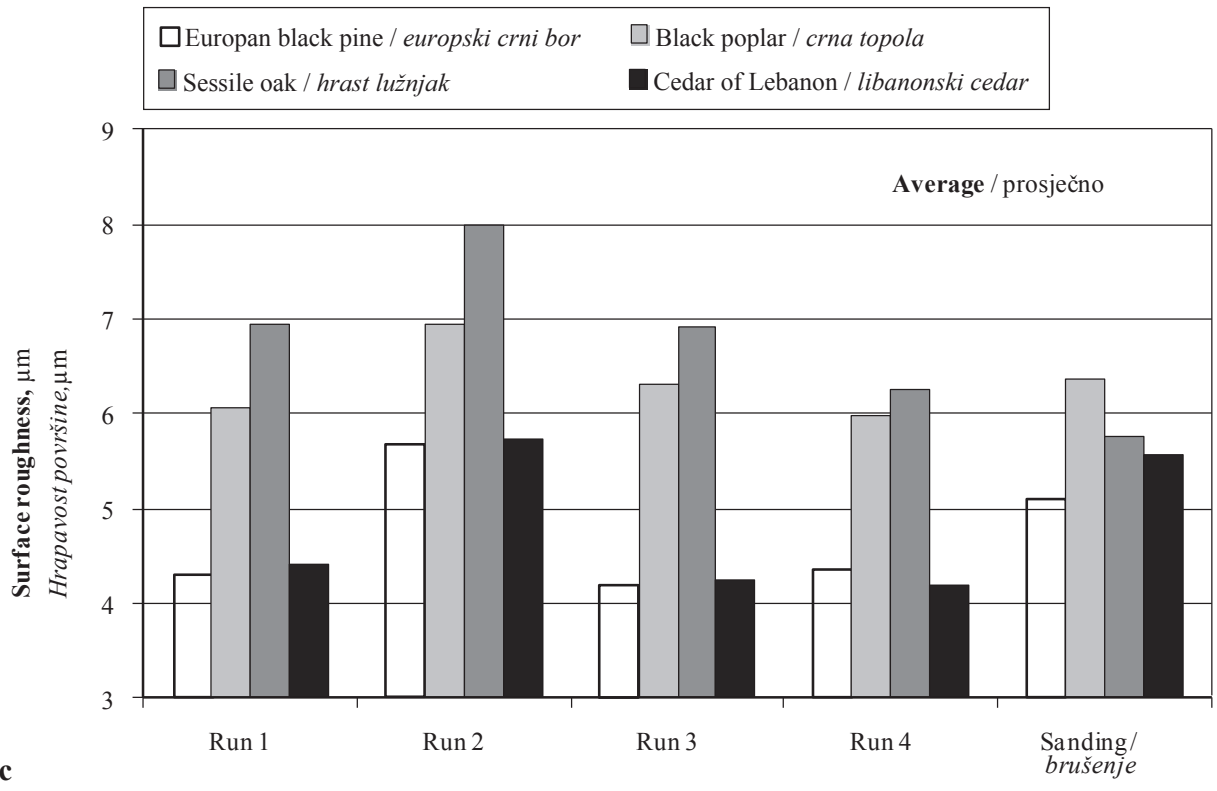

Figure 1a Roughness values along the grain for various machining (cutting type) conditions and tree species 1b Roughness values perpendicular to grain for various machining (cutting type) conditions and tree species 1c Mean Roughness values for various machining (cutting type) conditions and tree species

Slika 1. a) Vrijednosti hrapavosti uzduž vlakanaca za različite uvjete obrade i različite vrste drva; b) vrijednosti hrapavosti okomito na vlakanca za različite uvjete obrade i različite vrste drva; c) prosječne vrijednosti hrapavosti za različite uvjete obrade i različite vrste drva 
Table 2 General results for the measured roughness

Tablica 2. Rezultati izmjerene hrapavosti

\begin{tabular}{|c|c|c|c|c|c|c|c|c|c|c|c|c|c|c|c|}
\hline \multirow{3}{*}{$\begin{array}{l}\text { Wood species } \\
\text { Vrsta drva }\end{array}$} & \multicolumn{15}{|c|}{ Surface roughness / Hrapavost površine, $\mu \mathrm{m}$} \\
\hline & \multicolumn{3}{|c|}{$\begin{array}{c}\text { Run } 1 \\
\text { Prolazak } 1 .\end{array}$} & \multicolumn{3}{|c|}{$\begin{array}{c}\text { Run } 2 \\
\text { Prolazak } 2 .\end{array}$} & \multicolumn{3}{|c|}{$\begin{array}{c}\text { Run } 3 \\
\text { Prolazak } 3 .\end{array}$} & \multicolumn{3}{|c|}{$\begin{array}{c}\text { Run } 4 \\
\text { Prolazak } 4 . \\
\end{array}$} & \multicolumn{3}{|c|}{$\begin{array}{l}\text { Sanding } \\
\text { Brušenje }\end{array}$} \\
\hline & 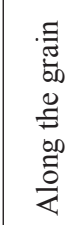 & 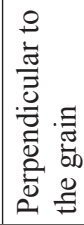 & 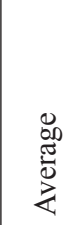 & 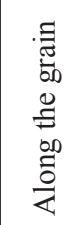 & 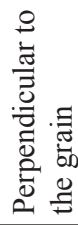 & 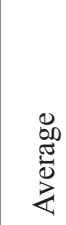 & 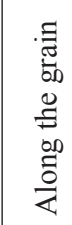 & 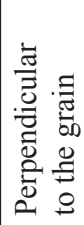 & 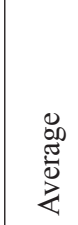 & 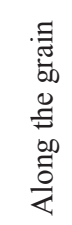 & 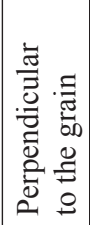 & 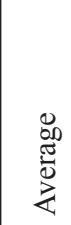 & 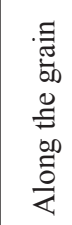 & 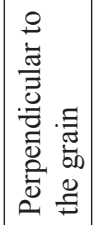 & 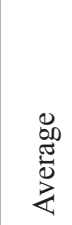 \\
\hline $\begin{array}{l}\text { Europan black pine } \\
\text { europski crni bor }\end{array}$ & 3.91 & 4.70 & 4.31 & 5.46 & 5.89 & 5.68 & 4.28 & 4.12 & 4.20 & 4.51 & 4.25 & 4.38 & 3.82 & 6.41 & 5.11 \\
\hline $\begin{array}{l}\text { Black poplar } \\
\text { crna topola }\end{array}$ & 4.87 & 7.22 & 6.05 & 6.17 & 7.73 & 6.95 & 5.03 & 7.61 & 6.32 & 4.83 & 7.14 & 5.98 & 4.29 & 8.46 & 6.37 \\
\hline $\begin{array}{l}\text { Sessile oak } \\
\text { hrast kitnjak }\end{array}$ & 5.81 & 8.08 & 6.95 & 6.70 & 9.30 & 8.00 & 6.03 & 7.79 & 6.91 & 4.68 & 7.82 & 6.25 & 4.26 & 7.28 & 5.77 \\
\hline $\begin{array}{l}\text { Cedar of Lebanon } \\
\text { libanonski cedar }\end{array}$ & 4.09 & 4.73 & 4.41 & 5.83 & 5.65 & 5.74 & 4.51 & 3.96 & 4.24 & 4.55 & 3.84 & 4.19 & 4.20 & 6.94 & 5.57 \\
\hline
\end{tabular}

Table 3 Average roughness values, standard errors based on tree species and lower and upper limits based on $95 \%$ confidence limit

Tablica 3. Prosječne vrijednosti hrapavosti, standardna pogreška za pojedinu vrstu drva, donja i gornja granica za interval pouzdanosti od $95 \%$

\begin{tabular}{|l|c|c|c|c|}
\hline \multirow{2}{*}{$\begin{array}{l}\text { Wood species } \\
\text { Vrsta drva }\end{array}$} & Arithmetic average & $\begin{array}{c}\text { Standard error } \\
\text { Aritmetička sredina }\end{array}$ & $\begin{array}{c}\text { 95 \% confidence limits } \\
\text { Standardna pogreška-tni interval pouzdanosti }\end{array}$ \\
\cline { 4 - 5 } & & 0.072 & 6.196 & 6.480 \\
\hline Black poplar / crna topola & 6.338 & 0.073 & 4.597 & 4.884 \\
\hline Europen black pine / europski crni bor & 4.740 & 0.072 & 6.638 & 6.922 \\
\hline Sessile oak / hrast kitnjak & 6.780 & 0.073 & 4.693 & 4.978 \\
\hline Cedar of Lebanon / libanonski cedar & 4.836 & & & $\begin{array}{c}\text { Upper limits } \\
\text { Gornja granica }\end{array}$ \\
\hline
\end{tabular}

roughness values were found in Run 1 and sanding, and the average roughness values for Run 3 and Run 1 exhibited close values when the upper and lower limit values of the Run 3 and Run 1 are studied based on a $95 \%$ confidence level, the limit values for both runs overlap. It was determined that the machining conditions of Run 4 had the lowest roughness average.

With regards to measurement direction, there was a significant difference between the measurement values along the grain and measurement values perpendicular to the grain (the average of the roughness values perpendicular to the grain is $1.553 \mu \mathrm{m}$ higher than the roughness value along the grain). Figure 2 shows the average roughness values $(\mathrm{Ra})$ along and perpendicular to the grain based on tree species in the form of graphs.

$R \mathrm{a}$ of poplar is $1.6077 \mu \mathrm{m}$ higher than that of pine. The average roughness value $R$ a of poplar is also 1.5048 $\mu \mathrm{m}$ higher than that of cedar of Lebanon. However, Ra of oak is $0.4417 \mu \mathrm{m}$ units higher than that of black poplar. The $R \mathrm{a}$ of pine is $2.0494 \mu \mathrm{m}$ less than that of oak. Although the $R$ a of pine is $0.1029 \mu \mathrm{m}$ less than that of cedar of Lebanon, there is no significant difference between the two. In other words, pine and cedar of Lebanon may

$\square$ Along the grain / duž vlakanaca $\square$ Perpendicular the grain / okomito na vlakanca

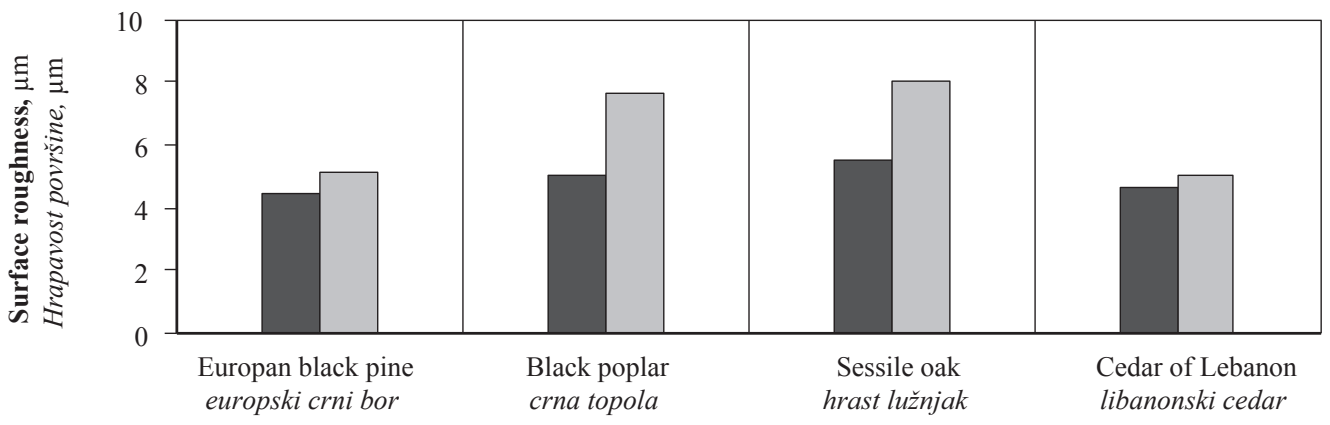

Figure 2 Graphs of average surface roughness along and perpendicular to the grain based on tree species Slika 2. Prosječna hrapavost površine istraživanih vrsta drva uzduž vlakanaca i poprečno na njih 
Dündar Sofuoğlu, Kurtoğlu: Effects of Machining Conditions on Surface Roughness... ......
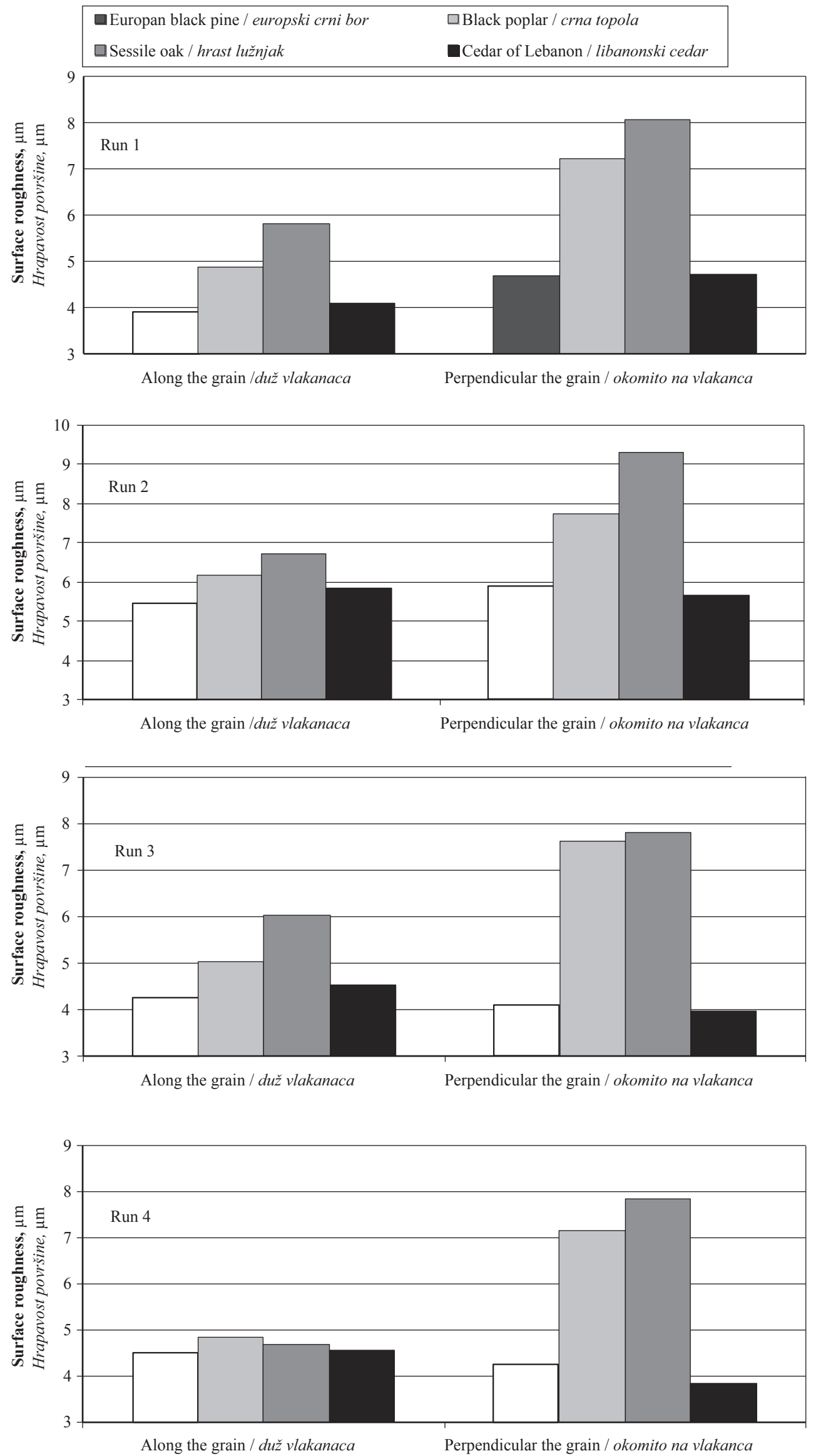

Figure 3 Average roughness values under machining conditions of runs 1, 2, 3, and 4 based on measurement directions and tree species

Slika 3. Prosječne vrijednosti hrapavosti u uvjetima obrade nakon 1., 2., 3. i 4. prolaska noža za različite smjerove mjerenja hrapavosti i različite vrste drva 


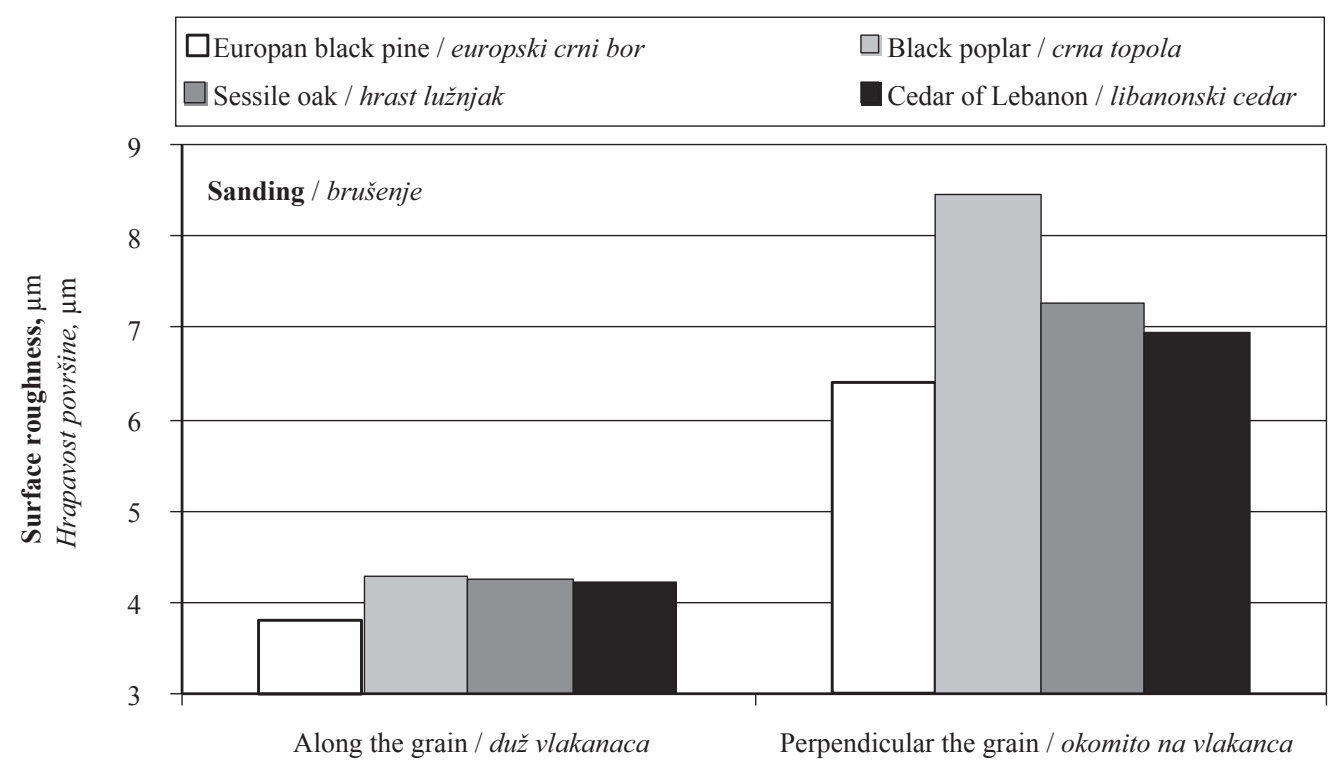

Figure 4 Roughness graph for sanding operation (cut type) based on measurement directions and tree species Sika 4. Izmjerena hrapavost nakon brušenja za različite smjerove mjerenja hrapavosti i za različite vrste drva

be gathered together under the same group with regards to roughness value. The Ra values for black poplar and oak are higher than those for the other tree species.

According to statistical analysis results, the $R \mathrm{a}$ for Run 2 was by $1.1737 \mu \mathrm{m}$ higher than for Run 1 . Although Ra for Run 1 was by $0.0218 \mu \mathrm{m}$ higher than for Run 3, there was no significance between them (Sig: 1,000) and Run 1 and Run 3 can be put into the same group with regards to roughness averages. While the value of $R$ a for Run 1 was by $0.2375 \mu \mathrm{m}$ higher than for Run 4 , it is by $0.2677 \mu \mathrm{m}$ less for sanding. The $R$ a for Run 2 exhibited a significant difference since they were higher compared to all the other machining conditions. The $R \mathrm{a}$ for sanding conditions have a slightly higher Ra compared to all the other machining conditions except for Run 2. Sanding machining condition can be shown as a separate group with regards to $R$ a. At the same time, although $R$ a for Run 3 was by $0.2158 \mu \mathrm{m}$ higher than for Run 4, these two machining conditions are shown under the same group with regards to roughness averages.

According to the statistical analysis results, there was no significant difference in roughness with regards to measurement directions. Figures $3 a, 3 b, 3 c$, and $3 d$ show the roughness graphs under machining conditions for Runs 1, 2, 3, and 4 based on measurement directions and tree species.

Figure 4 presents a roughness graph under sanding condition based on measurement directions and tree species.

\section{CONCLUSIONS}

\section{ZAKLJUČAK}

As a result, Sessile Oak showed the roughest surface in wood machining operations. According to the roughness measurement results for black poplar, surfaces with the highest faults and the roughest surfaces occurred in the sanding operation. Although it was expected that black poplar would have smoother surfaces during sanding, since the machining method affects surface quality, an increase in the roughness was observed. It is believed that this result is significantly affected by the type of procedure. Cedar of Lebanon exhibited values close to black pine with regards to average roughness, displaying the lowest average roughness values amongst the tree species studied. The values for black poplar and sessile oak were found to be higher. Cedar of Lebanon was in the same group as black pine in regards to surface roughness and exhibited the highest roughness value.

\section{Acknowledgement - Zahvala}

This study is a part of Doctorate Thesis prepared by Sait Dundar SOFUOGLU, Institute of Sciences, Istanbul University, Istanbul, Turkey.

\section{REFERENCES}

\section{LITERATURA}

1. Aras, R.; Budakçı, M.; Özışık, O., 2007: The effect of wood turning techniques on surface roughness of wood material. Journal of Polytechnic, 10: 325-330.

2. Aslandoğan, C., 2005: Research on determination of surface roughness of crimean pine (Pinus nigra Arnold) wood. MSc thesis, Hacettepe University, Ankara/Turkey.

3. ASTM International, 2004: Standart methods for conducting machining tests of wood and wood - base materials (Vol. ASTM D 1666-87 (Reapproved 2004)). West Conshohocken, United States.

4. Efe, H.; Gürleyen, L., 2003: Effects of the cutting direction the number of cutter and the rotation value on surface smoothness for some wood species. The Journal of the Industrial Arts Education Faculty of Gazi University, 11: $34-44$

5. Faust, D. T., 1987: Real time measurement of veneer surface roughness by image analysis, Forest Products Journal, 37: 34-40. 
6. Faust, D. T.; Rice, J. T., 1986: Effect of veneer surface roughness on the bond quality of Southern pine plywood, Forest Products Journal, 36: 57-62.

7. Gürleyen, L., 1998: A comparison on the surface smoothness in wood materials, Master Thesis, Gazi University, Institute of Science, Ankara.

8. Hiziroglu, S.; Zhong, Z. W.; Tan, H. L., 2013: Measurement of bonding strength of pine, kapur and meranti wood species as function of their surface quality. Measurement 46: 3198-3201. http://dx.doi.org/10.1016/j.measurement.2013.05.005.

9. İlter, E.; Çamliyurt, C.; Balkız, O. D., 2002: Researches of the determination of the surface roughness values of bornmullerian fir (Abies bornmülleriana Mattf.). Central Anatolia Forestry Research Institute, Turkey.

10. Kantay, R.; Ünsal, Ö.; Korkut, S., 2001: Investigation of surface roughness of sliced walnut and beech veneers produced in Turkey. Review of the Faculty of Forestry, University of İstanbul, 51: 15-31.

11. Malkocoglu, A., 2007: Machining properties and surface roughness of various wood species planed in different conditions. Building and Environment, 42: 2562-2567 http://dx.doi.org/10.1016/j.buildenv.2006.08.028.

12. Malkocoglu, A.; Ozdemir, T., 1999: Surface roughness of the historical development. Furniture decoration 32: 6068.

13. Örs, Y.; Baykan, İ., 1999: The effect of planing and sanding on surface roughness of massive wood. Turkish Journal of Agriculture and Forestry, 23: 577-582.

14. Örs, Y.; Demirci, S., 2003: The effect of cutting direction and sanding on the surface roughness of the acacia (Robinia pseudoacacia L.) and oak (Quercus petraea L.) Woods, Journal of Polytechnic, 6: 491-495.

15. Peters, C.; Mergen, A., 1971: Measuring wood surface smoothness: A proposed method, Forest Products Journal, 21: 28-30.

16. Peters, C. C.; Cumming, J. D., 1970: Measuring wood surface smoothness: A rewiew, Forest Products Journal, 20: 40-43.

17. Porter, A. W.; Kusec, D. J.; Sonders, J. L., 1971: Air flow method measures lumber surface roughness, Canadian Forest Industries.
18. Sandak, J.; Tanaka, C., 2005: Evaluation of surface smoothness using a light - sectioning shadow scanner. Journal of Wood Science, 51: 270-273. http://dx.doi.org/10.1007/s10086-004-0637-z

19. Škaljić, N.; Beljo Lučić, R.; Čavlović, A.; Obučina, M., 2009: Effect of feed speed and wood species on roughness of machined surface. Drvna industrija, 60: 229-234.

20. Söğütlü, C., 2005: The effect of some factors on surface roughness of sanded wood material. Journal of Polytechnic, 8: $345-350$ http://dx.doi.org/10.2339/y2005.v8.n4.p345-350.

21. Sönmez, A.; Söğütlü, C., 2005: The effect of planning on the surface roughness in wood material. Teknoloji, 8: 287-293.

22. Steward, H. A., 1970: Cross grain knife planing, hard maple produces high quality surfaces and flakes. Forest Products Journal, 20: 39-42.

23. Stumbo, D. A., 1960: Surface texture measurement for quality and production control. Forest Products Journal, 10: 122-124.

24. Ünsal, O.; Kantay, R., 2002: Investigation of surface roughness of oak and beech wood parquets produced in Turkey. Review of the Faculty of Forestry, University of İstanbul, 52: 81-94.

25. Zhong, Z. W.; Hiziroglu, S.; Chan, C. T. M., 2013: Measurement of the surface roughness of wood based materials used in furniture manufacture. Measurement, 46: 1482-1487 http://dx.doi.org/10.1016/j.measurement.2012.11.041.

\section{Corresponding address:}

\section{Dr. Sait Dündar SOFUOĞLU}

Department of Wood Works Industrial Engineering, Faculty of Simav Technology, Dumlupinar University 43500 Simav - Kutahya / TURKEY e-mail:sdsofuoglu@gmail.com 